\title{
Analysis of the ability in mathematical problem-solving based on SOLO taxonomy and cognitive style
}

\author{
Usman Mulbar, Abdul Rahman \& Ansari S. Ahmar \\ Universitas Negeri Makassar \\ Makassar, South Sulawesi, Indonesia
}

\begin{abstract}
The aim of this study is to obtain a description of the mathematical problem-solving ability of first year students of the Statistics Department at Universitas Negeri Makassar, Makassar, South Sulawesi, Indonesia, based on the SOLO taxonomy and the cognitive style. This study uses a qualitative explorative method. The hypothesis of the study was that students who exhibit a field independent (FI) cognitive style have a higher level of capability in terms of the SOLO taxonomy levels for problem-solving of mathematics than students who have the field dependent (FD) cognitive style. The results of this study show that a SOLO taxonomy level for the GK-FD subject is pre-structural and the GK-FI subject is uni-structural.
\end{abstract}

\section{INTRODUCTION}

In these sophisticated times, many modern tools have become invaluable in overcoming problems. The period is called the era of science and technology, and human life can no longer be separated from science and technology. One of the foundations supporting the development of science and technology as it is today, is mathematics. Sudrajat said that the rapid development of science and technology has been enabled through the support of mathematics [1]. The cornerstone of the support comes from the strength of the structure and mathematical reasoning. The development of mathematics is often pioneering new application opportunities in other fields through using cognitive and learning styles. In mathematics learning, students require numerous adjustments before mastering their progress cognitive style [2]. Learning styles affect the students' learning procedure and knowledge about them can be utilised as a part of designing learning [3].

Mathematics is a frightening spectre for most students. Students are afraid, because it is difficult to solve problems. Most of the students' difficulties come in the form of understanding the purpose of the given problem, understanding what is being asked about or students' lack of understanding of the material related to the issue. In addition, sometimes students make errors in their calculations.

Mathematics skills have been defined by the National Council of Teachers of Mathematics (NCTM): mathematical skills include the ability to dig, suspect, and make excuses, login to solve non-routine problems, communicate about and through mathematics, and link various ideas in mathematics and between mathematics and other intellectual activity [4].

However, many students are still experiencing difficulties in solving mathematical problems for teaching and learning activities, as well as in the execution of chores. Based on the experience of researchers in teaching in the classroom, most students still suffer from confusion in solving mathematical problems. This is also supported by the research findings of Romagnano that three dilemmas are central to the teaching and learning of mathematics; namely, 1) the ask them or tell them dilemma; 2) the good problems dilemma; and 3) the grading dilemma [5]. From the three dilemmas, dilemma two is concerned with respective difficulty of solving problems.

Mayer et al [6] researched the results presented by Silver and Cai [7] and found that students had difficulty in solving mathematic problems, because they found it difficult to understand the language problem. In addition, questions containing propositions and relationships are more difficult for students in comparison to assignments with questions containing propositions. Student creativity is needed in this case to overcome the difficulties in solving mathematical problems.

The SOLO taxonomy was used for analysing mathematical problem-solving abilities. The SOLO (structure of the observed learning outcome) taxonomy was originally proposed by Biggs and Collis [8] and is based on an idea from 
1982, by introducing an approach to evaluate and categorise cognitive abilities by considering the observation structures on learning outcomes. In the field of mathematics, SOLO models are used in assessing student cognitive outcomes in some expertise and scope of mathematics, including statistics, algebra, probability, geometry, fault analysis and problem-solving [9].

Good and Brophy said that people with low psychological differentiation (field dependent) have difficulty in distinguishing stimuli from the context in which they are placed (combined), so that they are easily influenced by the perception of manipulation of the surrounding context [10]. While people with high psychological differentiation (field independent) are more analytic, they can separate stimuli from the context, so that they are less affected by perceptions of changes in context (included). In other words, there are differences in cognitive style between students.

From the foregoing, it is known that the ability to solve problems is better if the topic is of particular interest to a student. On the other hand, there are still many students who do not have this capability. Furthermore, when students have been able to solve a problem, it turns out that they students have different ways of processing the data on a given problem. This method has been defined as creativity. This fact is what prompted the authors to examine the mathematical problem-solving ability of students based on the SOLO taxonomy and in terms of cognitive style.

\section{LITERATURE REVIEW}

\section{Problem-solving}

Bell argued that a situation/information is said to be an issue for someone, if they are not aware of the situation/ information, recognise that the situation/information requires action, but are not immediately able to find a solution [11].

Hudoyo is more interested in seeing the problem in relation to the procedures used by someone to finish it by their capacity ability [12]. It is asserted that someone might be able to solve a problem with a routine procedure, but others solve it in a non-routine way. Furthermore, Hudoyo suggested that two conditions need to be met for a question to be a problem for students: a) the question must be understood by the students, but it is a challenge for them to answer; and b) these questions cannot be answered with a routine procedure known to college students [13].

Sutawidjaja [14] suggests four things that might happen when one is facing a mathematics problem: a) one directly knows or has an idea of its solution, but has no desire to solve the problem; b) one has an overview of the solution and wishes to solve the problem; c) one has no idea about the solution, but wishes to solve the problem; d) one does not have an overview of the solution and has no desire to solve the problem. Furthermore, he said that if the situation relates to (c) above, it is said that the problem was an issue. So, in order for a problem to be of concern, it needs two conditions: 1) a solution to the problem cannot be described; and 2) solving the problem is desired.

Based on an understanding of the problem as stated above, it can be said that a question/certain mathematical problem can be a problem for some people, but not necessarily a problem for others. In other words, a mathematics problem may be a problem for someone at a certain time, but not necessarily a problem for them at another time. For example, take the following geometry problem: ...Prove that the sum of the angular size of each triangle is equal to $180^{\circ}$.

For most elementary school students, this question is not a problem, because they are not interested in solving it. Similarly, for junior high school students, the question is also not a problem, because they do not have any interest in solving this problem, but it may be a problem for high school students, and one they would like to solve. However, if they have no idea how to prove the matter, it is an issue for them [14].

Polya [15] divides the problem into two kinds; namely, a) the problem of finding; and b) the issue to prove. The problem of finding a way can be theoretical or practical, abstract or concrete, including puzzles, but the issue to prove is to show that a statement is true or false and not both. Swadener suggests four types of problems in mathematics; namely, a) symbolic, such as: $3 x^{2}+2 x-5=0$; b) the words, about the story; c) geometry, relating to the elements of geometry; and d) others, such as determining the formula [16].

\section{SOLO Taxonomy}

The SOLO taxonomy was first introduction by Biggs and Collis in 1982 in New York, United States [8]. SOLO, which is an acronym of the structure of the observed learning outcome. The SOLO taxonomy set up a systematic way to describe the performance of a student when studying or completing a task, especially the type of tasks performed at school. The SOLO taxonomy classifies the ability of learners according to the level/degree of their cognitive abilities in solving problems. This taxonomy consists of five levels/tiers: pre-structural, uni-structural, multi-structural, relational and extended abstract. Levels within the SOLO taxonomy is a hierarchical set of tiers based on the cognitive abilities of learners, in the sense that the uni-structural level is higher than the pre-structural level. Table 1 details the student response indicator used by the SOLO taxonomy role in this study, as adjusted for indicators according to Chick [17] and validated experts [18]. 
Table 1: Indicators of student response based on the SOLO taxonomy.

\begin{tabular}{|c|c|c|}
\hline No. & Level response & Indicator \\
\hline 1 & Pre-structural & $\begin{array}{l}\text { - Students use wrong data or process of solving so their conclusion is } \\
\text { incorrect or irrelevant. } \\
\text { - Students have little information that does not have relationship, so it } \\
\text { does not form a unified concept at all and does not have any meaning. } \\
\text { - Students cannot work on a given task correctly meaning that students } \\
\text { do not have skills that can be used to accomplish a given task. }\end{array}$ \\
\hline 2 & Uni-structural & $\begin{array}{l}\text { - Students use at least one piece of information, and use a concept or } \\
\text { solving process. } \\
\text { - Students using a process based on the data selected to correctly solve } \\
\text { the problem, but irrelevant conclusions are obtained. }\end{array}$ \\
\hline 3 & Multi-structural & $\begin{array}{l}\text { - Students use multiple data/information, but find no relationship } \\
\text { between the data, so they cannot draw relevant conclusions. } \\
\text { - Students can make some connection between several data/information } \\
\text { sources, but these relationships are not appropriate, so that the } \\
\text { conclusions obtained are irrelevant. }\end{array}$ \\
\hline 4 & Relational & $\begin{array}{l}\text { - Students use multiple data/information to the applied concept/process } \\
\text { and provide interim results and, then, connect the data or other } \\
\text { processes, so that they can draw relevant conclusions. } \\
\text { - Students associate the concept/process, so that all relevant information } \\
\text { is connected and relevant conclusions are obtained. }\end{array}$ \\
\hline 5 & Extended abstract & $\begin{array}{l}\text { - Students use multiple data/information, then, apply the } \\
\text { concept/process and provide interim results and, then, connect the data } \\
\text { or other processes, so that they can draw conclusions that are relevant } \\
\text { and can generalise about the results obtained. } \\
\text { - Students think conceptually and can generalise in a domain/area of } \\
\text { knowledge and experience of others. }\end{array}$ \\
\hline
\end{tabular}

Cognitive Style

Cognitive style refers to the way people obtain information and use strategies for responding to an assignment. It is known as style and not as ability, because it refers to how people process information and solve problems, and does not refer to the best method. Some experts, such as Messick [19], Zelniker [20], and Waber [21] provide definitions of similar cognitive styles, i.e. the tendency of a person who is relatively fixed in accepting, thinking and solving problems and remembering information [22]. There are two cognitive styles that are specifically important in education: fielddependent versus field-independent and impulsive versus reflexive. Each of these cognitive styles is based on differences in the psychological and conceptual differences tempo.

Witkin said that people who have the field-independent cognitive style respond to a task in a way that tends to lean or is based on the requirements from within themselves [23]. Meanwhile, people who have the field-dependent cognitive style see environmental requirements as a user in response to a stimulus. Further, Witkin said that people who have a field-independent cognitive style are more analytical, and they can choose the stimulus based on the situation/information, so that perception is only a small part that is affected when there is a change in the situation/information [23][24].

Meanwhile, people who have a field-dependent cognitive style have difficulty in distinguishing between stimuli through situations/information possessed, so they are easily influenced by the perception of manipulation of the situation/information around them. In detail, Good and Brophy [10] noted the difference in the two kinds of implications of cognitive style of students in mathematics learning in the classroom, as depicted in Table 2.

Table 2: Learning process based on student cognitive style.

\begin{tabular}{|c|c|}
\hline \multicolumn{2}{|c|}{ Student learning process } \\
\hline Field-dependent & Field-independent \\
\hline 1. Acceptance globally & 1. Acceptance analytically \\
\hline 2. Understand globally given its structure & $\begin{array}{l}\text { 2. Understand in the articulation of a given } \\
\text { structure or restriction }\end{array}$ \\
\hline $\begin{array}{l}\text { 3. Make a general and broad differences between concepts, } \\
\text { view of relationships/ linkages }\end{array}$ & $\begin{array}{l}\text { 3. Make a difference in specific concepts with } \\
\text { minimum overlap }\end{array}$ \\
\hline 4. Social orientation & 4. Orientation is not individual \\
\hline
\end{tabular}




\begin{tabular}{|ll|r|}
\hline 5. & Learning material that is more social & 5. $\begin{array}{l}\text { Learning social topics only as tasks that are } \\
\text { intentional }\end{array}$ \\
\hline 6. & The good material is material relevant their experience & $\begin{aligned} \text { 6. } \\
\text { Very interested in the new concept for the } \\
\text { benefit to themselves }\end{aligned}$ \\
\hline 7. & Requires external assistance and strengthening to \\
achieve the goal & 7. $\begin{array}{l}\text { The objectives can be achieved alone by the } \\
\text { strengthening of their own }\end{array}$ \\
\hline 8. & Requires organising & 8. Able with own structure situations \\
\hline 9. & More influenced by criticism & 9. A little affected by criticism \\
\hline 10. & Using long experienced approach to achieve the concept & $\begin{array}{l}\text { 10. Adopting the hypothesis testing to achieve the } \\
\text { concept }\end{array}$ \\
\hline
\end{tabular}

\section{METHOD}

This research employs a qualitative explorative method. The focus of this study is to determine the ability of problemsolving of mathematics students that have different cognitive styles based on the SOLO taxonomy. The population in this study were all first year students of the Statistics Department at Universitas Negeri Makassar. Identifying the subjects for this study was based on the results of cognitive style tests. Based on the results of these tests, students were placed into two groups: a group of students who have the field-independent (FI) cognitive style and a group of students who have the field-dependent (FD) cognitive style. The researchers themselves collected the data and used supporting instruments; namely, the group embedded figures test (GEFT) and the test of ability in mathematical problem-solving.

\section{RESULTS AND DISCUSSION}

Data on the cognitive styles of students in this study were obtained from the results of tests of cognitive style on 32 students of first-grade students in the Statistics Department at Universitas Negeri Makassar. Table 3 includes the results of tests of cognitive styles.

Table 3: Description of students’ cognitive style.

\begin{tabular}{|l|c|c|c|}
\hline \multirow{2}{*}{ Respondents } & \multicolumn{2}{|c|}{ Cognitive style } & \multirow{2}{*}{ Total } \\
\cline { 2 - 3 } & FI & FD & \\
\hline First year & 28 & 4 & 32 \\
\hline Percentage & 87.5 & 12.5 & 100 \\
\hline
\end{tabular}

Table 3 shows that of the 32 students who took the tests of cognitive style, 28 (87.5\%) students were in the fieldindependent cognitive style group (GK-FI), and 4 (12.5\%) of students who were in the field-dependent cognitive style (GK-FD) group. Four students from among the research subjects were examined in greater detail, comprising two students from each group. Also, further data about cognitive styles were taken from first-year students in the Statistics Department at Universitas Negeri Makassar who took the GEFT tests.

In this section, there is discussion about the research results of solving a mathematical problem according to the SOLO taxonomy submitted by students representing both the GK-FI and GK-FD groups, and discussion about the interesting case of the research results.

Question: An inverted conical tank that is $16 \mathrm{dm}$ high with a base radius $4 \mathrm{dm}$ has been erected. The tanks are filled with water at the rate of $2 \mathrm{dm}^{3}$ per minute. Determine the rate of increase in the radius of the water level in the tank when the water level $10 \mathrm{dm}$ !

Here are the results of the work done by a student of GK-FD.

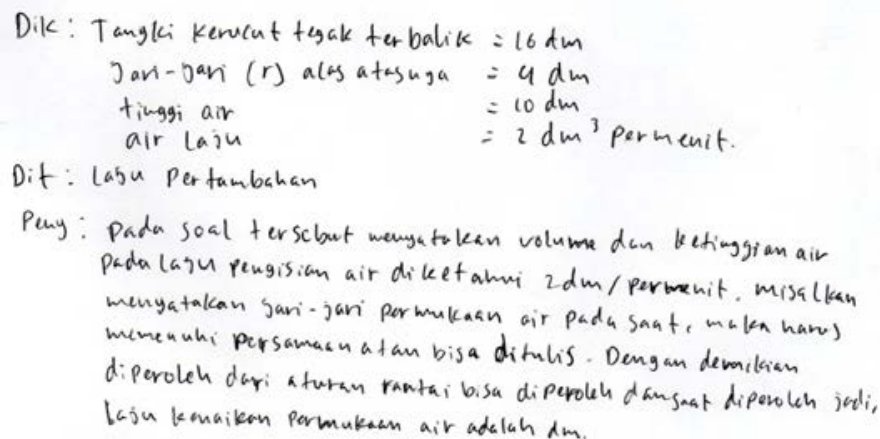

Figure 1: Result of the solution by a student of GK-FD. 
In this section, the GK-FD student used information obtained from the subject matter, e.g. a high data cone, cone radius and water rates, and was able to find out what the problem was. In the process of solving the problem, the student of GK-FD used approaches that are just observing what was obtained from the subject matter and did not really understand the concept of actual completion. The student of GK-FD used the concept of comparison of the rate of water, then, the results of that comparison were assumed into the next settlement that can be seen in Figure 2.

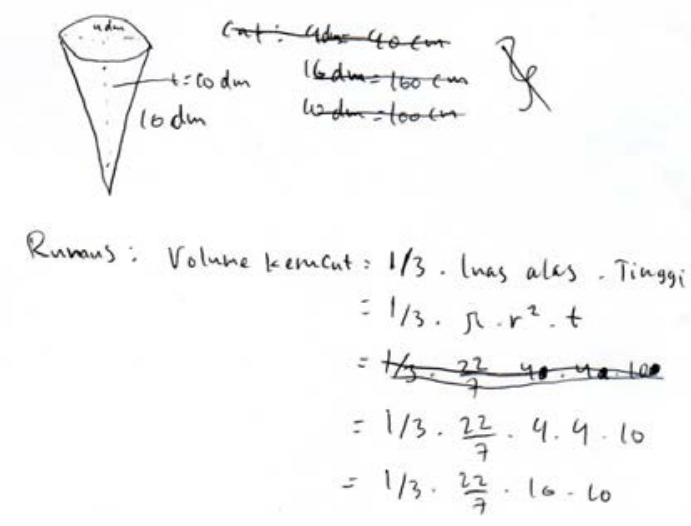

Figure 2: Result of solution by a student of GK-FD.

The student of GK-FD approached the problems by directly substituting the value of the radius of the base (4 dm) and high water $(10 \mathrm{dm})$. This student was in the process of solving the problem incorrectly, so that the conclusions have been obtained by improper or irrelevant means, also this student had little information that was not even related, so did not form a unitary concept at all and did not come up any meaning. In addition, GK-FD students have not been able to do the given task correctly. GK-FD means that the students do not have the skills that can be used to accomplish the given task. Based on these results, the students of GK-FD should be categorised into the pre-structural level of the SOLO taxonomy. The problems encountered by these students, due to the lack of knowledge of the concepts, principles and operation of this case, were approached in accordance with the opinion raised by Lipianto and Budiarto [25].

Here are the results of the work done by a student of GK-FI.
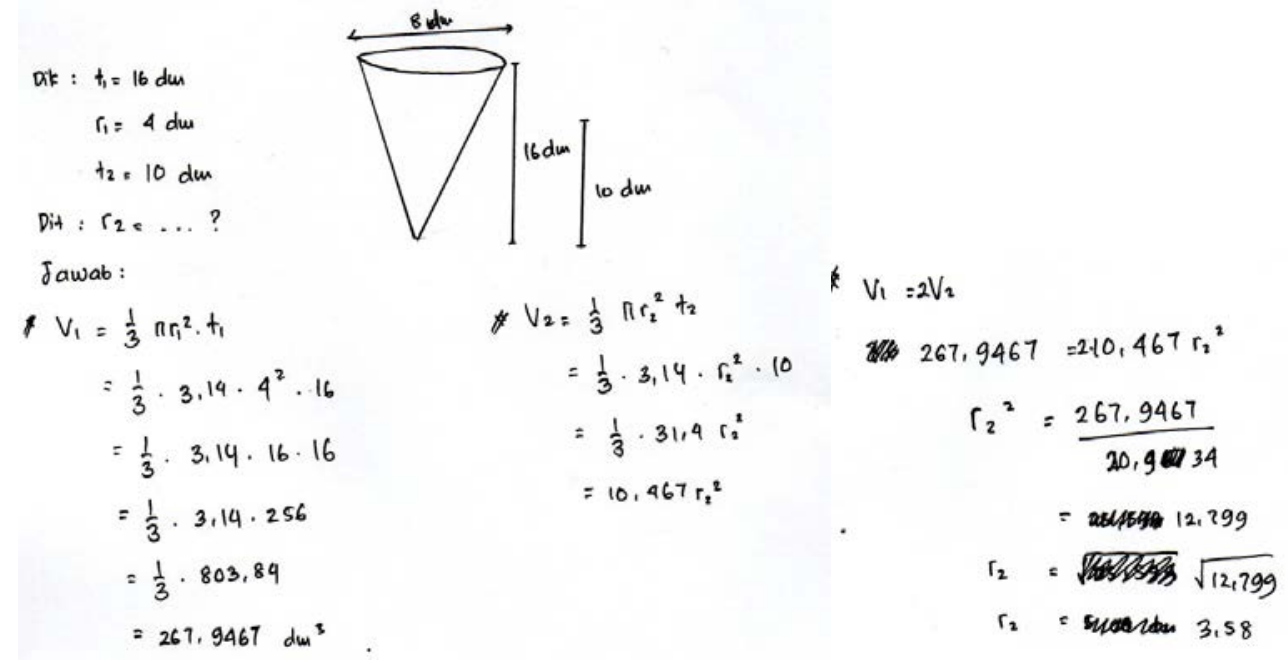

Figure 3: Result of solution by a student of GK-FI.

In this section, the student of GK-FI used the information obtained from the subject matter (section known), as well as from their own skills. This student also knew what the problem of this matter was. In the process of solving this student used approaches that were just observing what was obtained from the matter and had a provisional hypothesis or conjecture.

The student of GK-FI approached the problem by testing the hypothesis initially. This student achieved a high ratio using the rules of the tip of the cone. This student, then, calculated the volume ratio for each condition as a condition when the high water was $10 \mathrm{dm}$ and $16 \mathrm{dm}$. This comparison was to obtain the value of the radius at the time of filling water up $10 \mathrm{dm}$. From this process, it can be seen that the student of GK-FI used at least one information and applied a concept or process breakdown (volume ratio), but his/her conclusion was not relevant to any question. Based on these results, students of GK-FI should be categorised into a uni-struktural level of the SOLO taxonomy and the problems encountered by these students, due to the lack of knowledge of the concepts, principles and operation of this case, were approached in accordance with the opinion raised by Lipianto and Budiarto [25]. 


\section{CONCLUSIONS}

Based on the analysis of research data in the previous section, some of the conclusions from the results of this study are: 1) SOLO taxonomy levels for students of GK-FD are at the pre-structural and for students of GK-FI at uni-structural; 2) according to the SOLO taxonomy, students of GK-FD and students of GK-FI have a bottleneck in solving problems; namely, a) students do not have the readiness and lack planning skills to solve the problem; b) students applied the formula or formulae or process, but the process was not appropriate to solve the problem.

\section{ACKNOWLEDGEMENT}

The authors would like to express their thanks to Professor Dr Husain Syam, M.TP., Rector of Universitas Negeri Makassar for the opportunity provided to the authors to carry out this research, and to the management of the Research Institute of Universitas Negeri Makassar for facilitation of this research. This work was supported by funds provided by the DIPA Universitas Negeri Makassar (Grand Number: SP DIPA-042.04.2.400964/2016, 7 December 2015 and Number: 1186/UN36/LT/2016, 28 March 2016).

\section{REFERENCES}

1. Sudradjat, Peranan matematika dalam perkembangan ilmu pengetahuan dan teknologi. One-Day Seminar of The Power of Mathematics for all Aplications UNISBA (2008) (in Indonesian).

2. Rahman, A. and Ahmar, A.S., Exploration of mathematics problem solving process based on the thinking level of students in junior high school. Inter. J. of Environ. Science Educ., 11, 14 (2016).

3. Rahman, A., Ahmar, A.S. and Rusli, The influence of cooperative learning models on learning outcomes based on students’ learning styles. World Trans. on Engng. and Technol. Educ., 14, 3, 425-430 (2016).

4. National Council of Teachers of Mathematics, Curriculum and Evaluation Standards for School Mathematics. National Council of Teachers (1989).

5. Romagnano, L., Wrestling with Change: The Dilemmas of Teaching Real Mathematics. Heinemann Educational Books (1994).

6. Mayer, R.E., Larkin, J.H. and Kadane, J.B., A Cognitive Analysis of Mathematical Problem-Solving Ability. Erlbaum (1984).

7. Silver, E.A. and Cai, J., An analysis of arithmetic problem posing by middle school students. J. Res. Math. Educ., 27, 5, 521 (1996).

8. Biggs, J. and K. F. Collis, SOLO taxonomy, Educ. News, 17, 5, 19-23, (1980).

9. Lim, H.L., Wun, T.Y. and Idris, N., Kebolehan penyelesaian persamaan linear: satu kerangka dalam penaksiran bilik darjah (2009) (in Malaysian).

10. Good, T.L. and Brophy, J.E., Educational Psychology: a Realistic Approach. (4th Edn), Longman/Addison Wesley, Longman (1990).

11. Bell, F.H., Teaching and Learning Mathematics (in Secondary Schools). New York, NY: WC Brown Company (1978).

12. Hudoyo, H., Strategi Pembelajaran Matematika. Malang: IKIP Malang (1990) (in Indonesian).

13. Hudoyo, H., Pengembangan kurikulum matematika dan pelaksanaannya di depan kelas. Surabaya: Usaha Nasional (1979) (in Indonesian).

14. Sutawidjaja, A., Pemecahan Masalah dalam Pembelajaran Matematika. Makalah disajikan dalam seminar nasional (1998) (in Indonesian).

15. Polya, G., How to Solve it. A New Aspect of Mathematical Method. (2nd Edn), Princeton University Press (1973).

16. Rahman, A., Pengajuan masalah matematika ditinjau dari gaya kognitif dan kategori informasi. J. Ilmu Pendidik., 19, 2, 244-251 (2013) (in Indonesian).

17. Chick, H., Cognition in the formal modes: research mathematics and the SOLO taxonomy. Math. Educ. Res. J., 10, 2, 4-26 (1998).

18. Ekawati, R., Junaedi, I. and Nugroho, S.E., Studi respon siswa dalam menyelesaikan soal pemecahan masalah matematika berdasarkan taksonomi SOLO. Unnes J. Math. Educ. Res., 2, 2 (2013) (in Indonesian).

19. Messick, S., The nature of cognitive styles: problems and promise in educational practice, Educ. Psychol., 19, 2, 59-74 (1984).

20. Zelniker, T., Cognitive Style and Dimensions of Information Processing. In: Globerson, T. and Zelniker, T. (Eds), Cognitive Style and Cognitive Development. NJ: Ablex Norwood, 172-191 (1989).

21. Waber, D., The Biological Boundaries of Cognitive Styles: a Neuropsychological Analysis. In: Globerson, T. and Zelniker, T. (Eds), Cognitive Style and Cognitive Development. NJ: Ablex Norwood, 11-35 (1989).

22. Rahman, A., Analisis hasil belajar matematika berdasarkan gaya kognitif guru dan gaya kognitif siswa pada Kelas II SMU Negeri 3 Makassar, Makassar, Indonesia (2003) (in Indonesian).

23. Witkin, H.A., Moore, C.A., Goodenough, D.R. and Cox, P.W., Field-dependent and field-independent cognitive styles and their educational implications, ETS Res. Bull. Ser., 1975, 2, 1-64 (1975).

24. Witkin, H.A., The role of cognitive style in academic performance and in teacher-student relations, ETS Res. Bull. Ser., 1973, 1, 1-58 (1973).

25. Lipianto, D. and Budiarto, M.T., Analisis Kesalahan Siswa dalam Menyelesaikan Soal yang Berhubungan dengan Persegi dan Persegipanjang Berdasarkan Taksonomi SOLO Plus pada Kelas VIII, J. MatheUnnesa, 1, 1 (2013) (in Indonesian). 